\title{
Medicine and interest politics a study of decision-making processes in the area of vascular surgery in Norway
}

Decisionmaking in vascular surgery

Kjersti Wendt

Division of Emergencies and Critical Care, The Intervention Centre, University of Oslo Hospital, Norway

Bjørn Erik Mørk

Department of Strategy and Entrepreneurship, BI Norwegian Business School, Oslo, Norway and

Warwick Business School, Coventry, UK

Ole Trond Berg

Department of Health and Society, University of Oslo Faculty of Medicine, Oslo, Norway, and

Erik Fosse

Department of Emergencies and Critical Care, The Intervention Centre, Oslo universitetssykehus Rikshospitalet, Oslo, Norway and

Department of Clinical Medicine, University of Oslo Faculty of Medicine, Oslo, Norway

\begin{abstract}
Purpose - The purpose of this paper is to increase the understanding of organizational challenges when decision-makers try to comply with technological developments and increasing demands for a more rational distribution of health care services. This paper explores two decision-making processes from 2007-2019 in the area of vascular surgery at a regional and a local level in Norway.

Design/methodology/approach - The study draws upon extensive document analyses, semi-structured interviews and field conversations. The empirical material was analyzed in several steps through an inductive approach and described and explained through a theoretical framework based on rational choice (i.e. bounded rationality), political behavior and institutionalism. These perspectives were used in a complementary way.

Findings - Both decision-making processes were resource-intensive, long-lasting and produced few organizational changes for the provision of vascular services. Stakeholders at both levels outmaneuvered the health care planners, though by different means. Regionally, the decision-making ended up in a political process, while locally the decision-making proceeded as a strategic game between different departments and professional fields.
\end{abstract}

(C) Kjersti Wendt, Bjørn Erik Mørk, Ole Trond Berg and Erik Fosse. Published by Emerald Publishing Limited. This article is published under the Creative Commons Attribution (CC BY 4.0) licence. Anyone may reproduce, distribute, translate and create derivative works of this article (for both commercial and non-commercial purposes), subject to full attribution to the original publication and authors. The full terms of this licence may be seen at: http://creativecommons.org/licences/by/4.0/legalcode

The authors would like to thank Associate Editor Professor Suzanne Robinson and the anonymous reviewers for detailed and constructive comments on how the authors could further develop the paper. The authors are also indebted to all of the informants for the way that they contributed to the study. Finally, the authors are grateful to Associate Professor Thomas Hoholm for his suggestions on aspects to address when finalizing the paper.

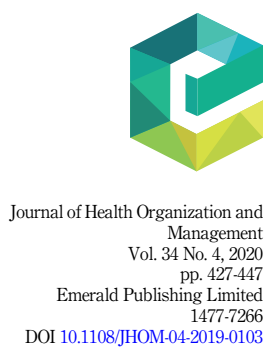

Received 16 April 2019 Revised 6 December 2019 13 February 2020

Accepted 1 March 2020

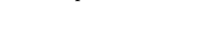


JHOM 34,4
Practical implications - Decision-makers need to prepare thoroughly for convincing others of the benefits of new ways of organizing clinical care. By providing meaningful opportunities for public involvement, by identifying and anticipating political agendas and by building alliances between stakeholders with divergent values and aims decision-makers may extend the realm of feasible solutions.

Originality/value - This paper contributes to the understanding of why decision-making processes can be particularly challenging in a field characterized by rapid technological development, new treatment options and increasing demands for more rational distribution of services.

Keywords Norway, Decision-making processes, Interest politics, Medical technological developments, Organizing health care

Paper type Research paper

\section{Introduction}

Decision-making in health care on financing, provision and distribution of services is challenging with competing logics of managerialism, professionalism and "localism" (Garpenby and Bäckman, 2016; Choi et al., 2011; Magnussen et al., 2007). Up until the mid1970s old models dominated clinical health care, in Norway as elsewhere. These models had grown, more than they had been planned and constructed. They reflected in various ways the central role of physicians in health care, but also to some extent national and local conditions. In most countries, third parties dominated the financing of health care, a system that came under increasing pressure after the Second World War. The tension between the dynamism of the supply side with technology as a key driver and the "automatic" financing of the demand made the system begin to crack in the 1970s. The pressure to adapt to an increasingly disruptive new technology and its offerings combined with the financiers' increasing inability to foot the growing health care bill, made non-incremental change "necessary". This change affected the interests of many important stakeholders, like groups of physicians, local communities and patients groups, often in a negative way. Thus, from the 1970s onward decisions about structural changes became engulfed in heated politics.

From the mid-1970s to the mid-1990s the modernizing decision-makers had more or less been treading water. But then, inspired by international trends and the growing authority of the "The Third Way" (Giddens, 1998) in public management, especially as it was carried out by Tony Blair and his New Labour in Britain (from 1997), key Norwegian (labor) politicians decided that something more radical had to be done. Thus, in 2002 they introduced a largescale reform and centralized control and ownership of all hospitals from the counties to the national government (Torjesen et al., 2017; Byrkjeflot and Neby, 2008). They thought that central politicians, influenced by strong management experts, might be more efficient modernizers than "parochial" local politicians and groups of professionals. In the wake of this hospital reform, the government and its new, professional hospital managers launched several new structural initiatives. This paper discusses findings from two such initiatives (one regional and one local) in the area of vascular surgery in Norway.

Similar initiatives were taken in most areas of somatic medicine in Western countries from the late 1990s and early 2000s. Politicians, managers and health care students began to realize that the old clinical models were becoming too expensive, inefficient and unable to provide equal and immediate access to high quality services. Christensen et al. (2008) proclaimed that health care was ripe for disruption, and their colleagues Porter and Lee (2013), that a new model of health care, the Integrated Practice Unit, was needed.

The decision-making processes we have studied were characterized by a tug-of-war between various forces of "the past" and "the future". The former includes local groups of physicians, lay people and politicians ideologically opposed to aspects of technically and financially driven modernization. The latter includes "modernizers" like some elite professional groups, parts of the central bureaucracy and technology businesses and other experts groups - like researchers and consultancies. The stakes might vary from situation to 
situation: stakeholders may at times be "traditionalists" and at other times "modernizers". The timing of initiatives and the mobilization of actors might also vary, sometimes turning the decision-making into "garbage can" like processes (Cohen et al., 1972). Lindblom (1959) characterized politics (decision-making) as the "science of muddling through".

The "modernizers" took the initiative to reorganize, indeed centralize, the vascular treatments at the South Eastern Norway Regional Health Authority (South Eastern RHA) and at Oslo University Hospital. The contention was that new technology and practices in endovascular treatments required a new, more concentrated, type of clinical organization and to some extent a new configuration of personnel. Our empirical material spans the period 2007-2019, and it is based on documents, interviews and field conversations.

Based on our analysis of the empirical material, we argue that it is useful to combine three theoretical perspectives to explain and describe the two decision-making processes. They were challenging to handle due to cognitive limitations and bounded rationality (Simon, 1947). The political perspective (enabled us to account for how multiple coalitions with different goals and interests used various tactics to reach their goals Pfeffer, 1981; Cyert and March, 1963), including non-decision-making (Bacharach and Lawler, 1980) and escalating indecision (Denis et al., 2011). Resonating the institutionalist perspective (March and Olsen, 1989), we observed how legitimacy, values and norms influenced how these decision-making processes unfolded. The theoretical framework is outlined further in Section 2.

In this article, we describe, characterize and try to unravel the logics underlying these decision-making processes. We discuss why those trying to restructure the organizations in question largely failed, and how they could have had a better chance of succeeding. Our study sheds light on the nature of "meta-clinical" decision-making processes taking place within a context characterized by rapid technological development, new treatment options and increasing demands for more rational distribution of services and where professionalism of various kinds' clashes with "lay" politics. By revealing some of the nature of such processes, we may contribute to improve how similar processes are managed.

\subsection{Background}

Norway has about 5.35 million people living in an area more than 1.5 times that of Great Britain. Before 1970, private or public organizations built and ran the hospitals. The Hospital Act of 1969 and a Parliament paper about hospital development in 1975 provided the premises for a more integrated hospital policy. Most publicly owned hospitals became county-owned and the responsibility of the 19 counties. A few highly specialized hospitals remained state-owned and the responsibility of the central government (Magnussen et al., 2007; Grønlie, 2006). This led to a professionalization of hospital management and a transition to population-based block grants (1980). However, the local authorities, often supported by groups of local health care personnel, were neither able nor willing to follow up the intentions behind the 1975 plan. Physician resistance and growing interprofessional rivalries often undermined the ability of the new directors to manage professionally. The results of these attempts to combine central control with local and to some extent health care professional autonomy were continued cost pressure, growing waiting lists and uneven quality. The state aimed at increased control and introduced an aggressive "New Public Management"-like centralization policy in the late 1990s. The hospital reform in 2002 was a significant element in policy. The responsibility and ownership for the Norwegian hospitals were transferred from the counties to the central government through a system of 5, later 4 (2007) regional health authorities which again were divided into local health enterprises (Byrkjeflot and Neby, 2008; Grønlie, 2006). The minister of health had full responsibility for conditions in the health sector, while the executive boards were given enhanced authority to set priorities and manage the regional and local health enterprises. Further, the hospital reform aimed to ensure

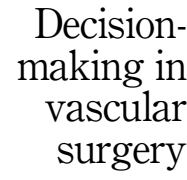

429 
JHOM 34,4

that "independent" leaders could make the "right" decisions concerning the development of medicine, its accompanying technology, the official goals of cost efficiency, quality and equity (Pinheiro et al., 2017). But this trade-off between political control and enterprise autonomy was challenging. Even though the boards were strictly professional without "political" members, politics did not disappear from the scenery. Instead it was channeled through media, protest movements and lobbying when the health enterprises tried to merge or close down hospitals (Lægreid et al., 2005). The enterprise reform has survived, but the pressure to "repoliticize" the boards and the governing of the hospital sector soon began to grow. From 2006, politicians were again allowed into the hospital enterprise boardrooms. Nevertheless, the board chairs and their directors have gradually tightened their control of the hospitals, supported by the central bureaucrats and the Ministry of Health and Care Services. A more precise and well-documented medicine also enabled them to set specific goals and to monitor practice more closely. (Torjesen et al., 2017; Byrkjeflot and Neby, 2008)

Medicine and medical technology went through the first real revolution in the years from 1944 (penicillin) to the early 1980s (Le Fanu, 1999). After some years of self-critical consolidation, it resumed its rapid growth into the 21st century. Vascular surgery, a specialty dealing with arterial diseases, veins and the lymphatic system outside the heart and brain, became part of this progress. As in the rest of Europe, vascular surgery was only sporadically performed in Norway until 1950. When thoracic surgery became a subspecialty in 1950 , vascular surgery became part of this specialty's domain. During the 1960s, vascular surgery was performed only at large regional hospitals. Gradually, as it became more standardized, it spread to smaller hospitals across the country. Vascular surgery became an independent subspecialty in 1986 (Myhre, 2012).

From the mid-1980s, the treatment of vascular disease changed dramatically from mainly open surgical procedures to more endovascular interventions (Goodney et al., 2009). Treatment of vascular disease progressed from the domain of intuitive to more probabilistic medicine (Christensen et al., 2008). Thus, the roles of both vascular surgeons and interventional radiologists changed. Vascular surgeons continued to diagnose and follow up patients postoperatively while the interventional radiologists gradually became more involved in the choice of treatment options. They also performed the actual treatment if an interventional procedure was indicated, thereby capturing some of the turf of the vascular surgeons.

\section{The decision-making system and its logic}

This study targets decisions formally made by collective decision-making bodies, including the boards of the regional health authority, the local health enterprises and to some extent the leaders of these and the various clinics. How we interpret this system and the various decisions that emerge from it depends on the theoretical perspectives that we draw upon. Our theoretical framework draws on three perspectives that we will use in a complementary way: rational choice (i.e. bounded rationality), political behavior and institutionalism. This section concludes with briefly presenting related research on merger and decommissioning of health care.

Rational choice is based on economic models and assumes that when individuals make decisions they have clear objectives, they conduct extensive information search about alternatives and their consequences, they prioritize between these alternatives, and they choose the optimal alternative (Simon, 1947). Decision systems therefore consist of interacting, competitive games where everyone tries to maximize their individual preferences (Scott, 2000). In contrast, one can assume that actors are completely arational. However, between these extreme views we find Simon's (1947) empirical research. He demonstrated that actors have cognitive limitations and limited problem-solving capacity. Hence, actors often have unclear goals, conduct limited search for alternatives, and they satisfice rather than optimize. Simon 
called this bounded rationality and considered decision-making processes as complex entities with elements of gaming, reactive adaptation and cooperation. Chance might also play a role (March and Simon, 1958). Eisenhardt and Zbaracki (1992) describe how rationality in decisionmaking moves along a continuum in various studies. Decision-makers sometimes appear effective and rational when they use various tactics and heuristics, while organizations compensate for the limitations of individual bounded rationality by aiming to have clear organizational goals and strategies and a clear division of labor through specialization and well-coordinated tasks. At other instances actors are reactively adapting, both normatively and strategically (March and Olsen, 1989; Dahrendorf, 1964). Although actors sometimes unite in communities making the individual almost disappear, these communities can act in egoistic ways, for example in budgetary processes. To account for such aspects, the political behavior perspective is particularly well suited.

The origin of the political behavior perspective on decision-making can be found in political science from the 1950s (Eisenhardt and Zbaracki, 1992). Organizations consist of coalitions of individuals with different objectives and interests, and these coalitions use various tactics to accomplish their conflicting goals. Whereas bounded rationality challenged the assumptions about cognitive capacity of individuals in decision-making, the political perspective challenged the assumption about organizations having one unified goal (Eisenhardt and Zbaracki, 1992; Cyert and March, 1963). It underscored that negotiations and strategic games are important, especially in organizations that are structurally differentiated, with many levels, units and departments. Negotiations have the prerequisite that actors have some common interests requiring them to collaborate (Pfeffer, 1981). In strategic games, actors purposefully use different tactics to promote their own interests at the expense of more general concerns (Williams, 2015; Werntoft and Edberg, 2015). These tactics can include lobbying, cooptation, coalition formation and controlling agendas (Pfeffer, 1981) as well as creating "escalating processes of indecisiveness" (Denis et al., 2011). Organizational decisionmaking processes take place in wider institutional settings.

Institutionalism underscores that organizations follow established norms and need to maintain legitimacy from the environment. Thus, institutions build upon historical experiences causing policy-making and institutional developments to follow distinct patterns (Byrkjeflot and Neby, 2008; March and Olsen, 1989). Consequently, health care planners need to consider external stakeholders with authority to constrain or facilitate decision-making processes. In publicly funded systems, these stakeholders are likely to include politicians, citizens and various interest groups (Williams, 2015). The desire to improve electoral prospects can sometimes lead politicians to adopt simplistic popularized positions on complex questions (Werntoft and Edberg, 2015; Williams, 2015). If the public is discontented with the outcomes and is excluded in the process, they may create legitimacy problems.

We will call those who required concentration of services, "modernizers," and those who wanted to incrementally adjust the existing systems - "traditionalists". Both withdrawal or full decommissioning of a service or treatment is considered as the most controversial approach to the removal or replacement of healthcare (Fredriksson and Moberg, 2018). Such actions are unpopular with the public even though they may increase cost-effectiveness and quality. Local activist groups tend to believe that decommissioning is driven only by financial and political concerns, and distrust and resent decision-makers (Williams et al., 2017). Consequently, decision-making processes often become "messy" and complex (Cohen et al. (1972).

\section{Methodology}

3.1 Choice of case

Case studies are well suited when real-time events and processes are not easily distinguishable from their context, and we want to draw upon different sources to
Decisionmaking in vascular surgery 
JHOM 34,4 understand the complexity of the cases (Yin, 2014). Our study explores how decision-making processes unfolded in the area of vascular surgery at two levels of the health care sector. We had wide access, both to the South Eastern RHA and Oslo University Hospital.

\subsection{Data collection}

We gathered the empirical material through extensive document analysis, interviews and field conversations. We collected the documents from 2012 to 2019. By using Google, Google Scholar, PubMed and libraries, we got access to reports, public inquiries, research papers, media prints and minutes from board-meetings at the South Eastern RHA and Oslo University Hospital. Two of the authors and the informants had access to informative internal documents, e-mails and notes. The informants, identified through the "snowball method" and from minutes from regional and local board meetings, contributed on request with copies of relevant documents. We conducted 13 interviews (Table 1) and performed regular field conversations. Some of the informants had participated in the decision-making processes both regionally and locally. One informant asked to participate after hearing about the study from one of the authors, whereas another person declined to participate for "loyalty reasons" to the employer. All informants signed an informed consent form.

The first author conducted all interviews. Apart from one telephone interview, all were conducted face to face. We asked questions about the informants' background and connection to the vascular surgical field before turning to the details of the actual decisionmaking process(es). The interviews lasted on average of one hour. We recorded all interviews and transcribed them verbatim.

\begin{tabular}{|c|c|c|c|c|c|c|}
\hline No. & Role & $\begin{array}{l}\text { Affiliation when } \\
\text { interviewed }\end{array}$ & $\begin{array}{l}\text { Background } \\
\text { information }\end{array}$ & Case 1 & Case 2 & $\begin{array}{l}\text { Date of } \\
\text { interview }\end{array}$ \\
\hline 1 & Manager & $\begin{array}{l}\text { South Eastern RHA* } \\
\text { admin. }\end{array}$ & $\mathrm{x}$ & $\mathrm{x}$ & & October 2012 \\
\hline 2 & $\begin{array}{l}\text { Manager/ } \\
\text { physician }\end{array}$ & $\mathrm{OUS}^{* *}$ & $\mathrm{x}$ & $\mathrm{x}$ & $\mathrm{x}$ & $\begin{array}{l}\text { November } \\
2012\end{array}$ \\
\hline 3 & Physician & Other RHA & $\mathrm{x}$ & & & $\begin{array}{l}\text { November } \\
2012\end{array}$ \\
\hline 4 & Physician & OUS & & & $\mathrm{x}$ & $\begin{array}{l}\text { December } \\
2012\end{array}$ \\
\hline 5 & Manager & OUS & & $\mathrm{x}$ & $\mathrm{x}$ & January 2013 \\
\hline 6 & $\begin{array}{l}\text { Manager/ } \\
\text { physician }\end{array}$ & OUS & & $\mathrm{x}$ & $\mathrm{x}$ & February 2013 \\
\hline 7 & Manager & OUS & & $\mathrm{x}$ & $\mathrm{x}$ & February 2013 \\
\hline 8 & Manager & $\begin{array}{l}\text { South Eastern RHA } \\
\text { admin. }\end{array}$ & & $\mathrm{x}$ & & March 2013 \\
\hline 9 & $\begin{array}{l}\text { Manager/ } \\
\text { physician }\end{array}$ & OUS & & $\mathrm{x}$ & $\mathrm{x}$ & March 2013 \\
\hline 10 & Manager & OUS & & $\mathrm{x}$ & $\mathrm{x}$ & April 2013 \\
\hline 11 & $\begin{array}{l}\text { Manager/ } \\
\text { physician }\end{array}$ & $\begin{array}{l}\text { Local hospital South } \\
\text { Eastern RHA }\end{array}$ & & $\mathrm{x}$ & & April 2013 \\
\hline 12 & $\begin{array}{l}\text { Manager/ } \\
\text { physician }\end{array}$ & $\begin{array}{l}\text { Local hospital South } \\
\text { Eastern RHA }\end{array}$ & & $\mathrm{x}$ & & May 2013 \\
\hline 13 & $\begin{array}{l}\text { Manager/ } \\
\text { physician }\end{array}$ & Other RHA & $\mathrm{x}$ & & & $\begin{array}{l}\text { September } \\
2016\end{array}$ \\
\hline Not & (s): RHA $^{*}=$ & al Health Authorit & Oslo Unive & Hospital & & \\
\hline
\end{tabular}$$
\text { verbatim. }
$$

Table 1.

Overview of the informants 


\subsection{Process of analysis}

We analyzed the empirical material in several steps through an inductive approach, often described as qualitative content analysis (Hsieh and Shannon, 2005). All authors individually read and reread the documents and the transcribed interviews before we discussed our interpretations. The first round of open coding gave us a general understanding of sequence of key events, key actors and responsibilities, board decisions, explanations for outcomes and so forth. Concepts and descriptions were kept close to the empirical material. We then performed axial coding to iteratively search for recurring and formative themes like decentralization vs centralization, distrust vs trust, professionalism, localism and politics. We paid particular attention to how different actors explained these processes and performed the analysis manually to preserve the richness of the material. The collection of the empirical material and our analysis proceeded concurrently to develop a thorough understanding of how the decision-making processes had unfolded. We also conducted "member checks" (Lincoln and Guba, 1986) with key informants by presenting our interpretations to them, and they also read drafts of the paper.

\subsection{Ethical considerations}

Norwegian Centre for Research Data approved the study. To maintain anonymity, we only present the informants by professional titles and numbers: (1) Managers (managers at different levels, staff positions, board members) and (2) Physicians (vascular surgeons or interventional radiologists). Audio recordings and digitally stored transcripts were password protected and safely stored.

\section{Findings}

\subsection{Story 1: the regional centralization efforts (2007-2018)}

The South and the East regional health authorities merged in 2007, motivated by the modern, industrial-type scale logic. The new CEO (former head of the Eastern RHA) and regional board immediately began identifying measures to realize what they assumed to be medical and economic scale advantages. This, for them, meant restructuring. Much of somatic medicine had become more "evidence-based" both diagnostically and therapeutically. More standardized treatments made it possible to provide more evenly and safely distributed services in a qualitatively and economically improved way. However, this required centers with high volumes of specialized procedures. The restructuring plan was ready by the end of December 2008 and marketed with the soothing slogan: "Centralize what needs to be centralized and decentralize what can be decentralized."

The RHA management divided the region into seven hospital areas, with 11 health enterprises. To advise them about the organization and provision of vascular services, the regional board appointed a committee of 22 members with a broad professional and geographic background. Henrik Sillesen, a Danish professor and vascular surgeon, who had participated in the centralization of vascular treatments in Denmark, was appointed as the leader. The board thereby indicated that it wanted to centralize the vascular treatments. This was in line with a previous report from the vascular surgical field itself (Norsk karkirurgisk forening, 2002). The CEO of the South Eastern RHA recused herself from leading the subsequent process, as her husband was managing the vascular surgical department at Aker Hospital (which shortly afterward became part of Oslo University Hospital). The board then appointed the vice president to this position only to replace him very quickly with the CEO from the Central RHA (Mid-Norway). These changes indicated that the management had prepared poorly for the process, thereby putting the "modernizers" on the defensive.

The Sillesen Committee presented its report in December 2009 and recommended to reduce regional vascular surgical departments from 8 to 3 (4), and establish a strong regional
Decisionmaking in vascular surgery 
JHOM 34,4

vascular center in Oslo by merging the vascular surgical departments at Aker Hospital and Rikshospitalet/Radiumhospitalet. It also proposed to divide vascular treatments into local, area and regional responsibilities, based on need volume and treatment complexity and to define a certain minimum yearly volume for surgeons/hospitals who performed the most complex vascular treatments. The intervention radiologists in the committee refused to specify minimum annual volumes for radiologists who performed endovascular repairs of abdominal aortic aneurysms. The committee disagreed about whether removal of vascular surgical competence from a hospital would affect other disciplines in the hospital negatively (Sillesen, 2009). The Sillesen committee played a modernizing and centralizing role and stirred up the local and traditionalist stakeholders. Yet, the reservations taken by some of the committee members also gave the "traditionalists" good arguments. Consequently, the committee did not give the "modernizers" the professional support they had anticipated.

The reaction from vascular surgeons, radiologists and the local communities that risked losing their vascular surgical department came quickly. Discussions about the regional provision of vascular services continued with great strength in the local media and reached a peak when the RHA board was to conclude at the end of 2010. The following quotes demonstrate how media supported the "traditionalists". "They saved my leg," a patient proclaimed in a newspaper headline with reference to the vascular surgeons at the Østfold hospital health enterprise, a hospital where vascular surgery was at stake. "Two hours transport to Oslo can be too long if there is a rupture of the aorta," a vascular surgeon at the same hospital added (Kristoffersen, 2010a). Politically dramatic casuistry tends to beat statistics.

A doctor at Vestre Viken, another regional health enterprise, demanded in another newspaper headline, the resignation of the regional $\mathrm{CEO}$ and claimed that the entire management of the RHA was disqualified due to personal relationships (Skiphamn, 2010). Vascular surgeons and radiologists at the hospitals where vascular surgery was at stake contacted their Parliament representatives and recommended them to intervene in the decision-making process. These politicians reacted quickly and asked for an extended report from the regional board about the possible consequences of removing vascular surgery from the hospitals in question. They also informed the Minister about the critical situation concerning the provision of vascular surgical treatments in the region and urged her to become involved. The Minister responded by referring to the recommendations of the Sillesen Committee, to the forthcoming board meeting and to ongoing case investigations (Sjølie, 2010; Kristoffersen, 2010b). Thus, with the support of the regional politicians and with media alerted, the local stakeholders managed to delay the decision-making process, which was a partial victory against the centralization plans.

The board reexamined the case on December 16, 2010. Most of the consultation responses were in agreement with the "centralist" view about volume and quality. Yet, a majority feared negative consequences for patients and other medical fields if vascular surgical competence was removed from any of the affected hospitals. Consequently, the chair recommended a risk assessment before the board concluded (Helse Sør-Øst, 2010). The "traditionalists" brought the "modernizers" somewhat on the defensive on professional premises.

In 2011, the chair appointed a new committee to perform a risk analysis for hospitals without vascular surgical competence and to investigate the future need for vascular services. He tried to choose "neutral" committee members to avoid further accusations of biased conclusions. Professor and clinical manager at the surgical department at St. Olav's hospital in Trondheim, Ola D. Sæter, was assigned as leader and six vascular surgeons and radiologists as members. This committee concluded in the Spring of 2011 that removal of vascular surgery was more serious for a hospital's reputation than for the treatment quality. Safe and effective treatment of vascular patients at centers with vascular expertise was considered more important than short distances to local hospitals with less expertise. 
The report confirmed that vascular surgical treatments were likely to increase, in particular endovascular treatments, and underscored that vascular surgeons and interventional radiologists had to cooperate (Sæther et al., 2011). This time the "modernizers", again lead by an academic specialist, got an argumentative advantage.

The conclusions from the Sillesen and Sæther committees were quite similar. Based on their recommendations the chair, at a regional board meeting in September 2011, concluded that the best long-term solution for the vascular service supply was to concentrate the vascular surgical activity in larger professional environments. Yet he, and the regional administration managers, had to consider how to respond to the resistance triggered by stakeholders at the hospitals and in the local communities. When they had reviewed the situation and the power configuration, they decided to give into some of the local demands and revoke the centralization plans. The chair said: "We need to proceed stepwise and evaluate the situation over time. The development in vascular surgery is connected to the development and prioritization of other disciplines in the hospital area." Thus, the provision of vascular services remained unchanged, but the resource use and the quality measures for the vascular procedures would be monitored closely. The health enterprises had to give vascular surgery higher priority and shift resources from passive alertness to active treatment (Helse Sør-Øst, 2011). The regional board approved these recommendations. It had reduced its modernizing ambitions and sensed that the board could trigger more opposition if it stuck to its original plans. After several challenging years, the debates at the regional level calmed down. Many of our informants were dissatisfied with the handling of this decision-making process.

Informant 1 said: "The conclusion was presented too brutally, without allowing enough time for preparation or process for the affected hospitals. The management should have had a humbler approach and a better dialogue with the participants in question." He/she favored a centralizing solution, but thought the centralizers' strategy had failed.

Informant 6 was against the "violent concentration" of vascular treatments suggested in the Sillesen report. He/she was not appointed to the committee even though other participants had recommended him/her to the management. He/she said: "Many people considered the report as a commissioned work." He/she thought that it was the centralizing elite professionals who stood behind the "commissioning."

Informant 11, a locally oriented "traditionalist", who preferred to work at his/her local hospital without too much central governance and interference stated: "After the Sceter report, it seemed like we could continue as before at the local hospitals. Activities at several treatment sites including endovascular repair of aortic aneurysms, started up again."

In contrast, informant 9 supported the proposed reduction of vascular departments because he/she believed this would provide better services and utilization of resources. He/ she said: "The case became political. I believe the regional management did not dare to remove vascular surgery from certain hospitals because there were political representatives also on the board. Nothing happened. In fact, vascular surgical activity is now increasing at local hospitals."

In 2018, we looked into the present organization of vascular services. The number of vascular departments had remained stable at eight since 2011. In a field conversation in May 2018, a manager at the South Eastern RHA's administration explained that the regional management had not received quality data from any specific vascular department after the final board decision in 2011. Instead, they had relied on information from the Norwegian Patient Register (NPR) and the clinical quality register for Norwegian vascular surgery (NorKar). However, NPR data provide information about numbers but little about quality, while NorKar provides incomplete quality data (NorKar, 2016). The manager concluded: "The centralization of vascular services became a political issue which made the interests of the local communities more crucial. The lack of centralization is also connected to the fact that the vascular surgical services at Oslo University Hospital have not yet been organized into a regional center."
Decisionmaking in vascular surgery 
JHOM 34,4

In short, the regional centralization efforts initiated an immense resistance from different local actors. Eventually, the regional politicians and even the Minister got involved, and the management at the regional authority had to alter their centralization plans. The organizational structures remained unchanged but the chair required the vascular surgical departments to turn in quality data to evaluate the situation over time. These requirements have seemingly not been sufficiently complied with and indicates how "poorly" prepared the "modernizers" were. They even came on the defensive as far as professional documentation and reasoning were concerned.

The leader of the board, and especially the CEO, were supporters of the centralizing plans developed by members of the professional elite. But they were not as insulated from happenings among local professionals and the wide variety of stakeholders, as the depoliticizing reforms implied. They were surprised by the reactions, channeled through the media and into Parliament and modified their position in the vain hope of winning time (Table 2). The new, self-assured management of goal-orientation and professional documentation lost out to the old politics of "muddling through" (Lindblom, 1959).

\subsection{Story 2: the local centralization efforts (2009-2019)}

Oslo University Hospital was established 1 January 2009, by the merger of Rikshospitalet (including the former Radiumhospitalet), Ullevål and Aker Hospitals. National-, regional- and local functions were thereby gathered into one organization. Oslo University Hospital became the country's largest hospital with 1,500 beds, 23,000 employees and a budget of NOK $22 \mathrm{bn}$ (2018). The hospital board appointed a temporary CEO, who was replaced in July 2009.

The management of the Department of Vascular Diseases at Oslo University Hospital was situated at Aker Hospital, while vascular surgery was performed at all of the merged entities. Most of the vascular surgeons worked at Aker Hospital with responsibility for vascular patients from the local and semi-local area covered by the health enterprise. These surgeons also conducted outpatient consultations and had a national circulation physiology laboratory for research and patient examinations. They also rotated in shifts and performed treatments on multitraumatized patients at Ullevål Hospital. At Rikshospitalet a small number of vascular surgeons, employed at the Department of Cardiothoracic Surgery, had responsibility for national and regional level patients.

The first attempts to colocate the vascular treatments at Oslo University Hospital began shortly after the merger, based on decisions made by the regional board (Helse Sør-Øst, 2010; Helse Sør- $\varnothing$ st, 2008) and handled in a project called " $P$ - 5 ". It recommended transferring the hospitalized vascular patients from Aker Hospital to Rikshospitalet and have the surgical procedures performed at its Intervention Centre. This research and development (R\&D) centre was equipped with a combined surgical and radiological suite and two other suites with advanced imaging equipment integrated in an operation room environment. The planned transfer of vascular surgical patients to Rikshospitalet meant that the centre had to expand its facilities and employ more personnel. This initiated a process with numerous meetings about design, technological equipment and the relocation of the surgical staff members from Aker Hospital. Simultaneously, the management at Oslo University Hospital tried to find locations for postoperative beds and wards for the new vascular patients. This was challenging because of limited space at Rikshospitalet.

Concurrently, other important organizational issues came up at Oslo University Hospital. In February 2010, the board decided to close down Aker Hospital, sell all or part of the property and invest in new hospital facilities (Hatlen, 2010). These plans triggered a storm of protests among local citizens, patients, local health professionals and local politicians. The impending closure of Aker Hospital was steadily debated in the media (Werner-Erichsen, 2012; Skjebstad, 2010). After some turbulent months, the Aker area became regulated for 


\begin{tabular}{ll}
\hline Year & Event \\
\hline 2007 & $\begin{array}{l}\text { The merger of the South } \\
\text { and the East RHA }\end{array}$ \\
2008 & $\begin{array}{l}\text { A strategic plan for the } \\
\text { merged regional } \\
\text { authority is completed }\end{array}$
\end{tabular}

2009

The provision of vascular services is investigated

CEO resigns from regional vascular reorganizing process because she is married to manager of vascular surgical department at Aker hospital. Vice president is assigned

2010 Vice president resigns from process, $\mathrm{MD}$ from Central RHA is assigned

Strong local resistance against the perceived decommissioning of vascular departments

Board meeting to comply with resistance and consultation responses

2011 The Sæther report (risk assessment)

Board meeting

Participants
The government,
the Parliament
The regional CEO,
the regional board,
consultation groups

Decisions/actions

Realize medical and economic scale advantages

"Centralize what needs to be centralized and decentralize what can be decentralized"

The regional board, various professional and expert groups, The Sillesen Committee Regional board

Regional board Reduce number of vascular centers and establish a strong regional vascular center in Oslo The regional management aims to appear unbiased and qualified in managing the process

Local professionals, citizens, patient groups, media and politicians

The regional board

Seven committee members

The regional board

The regional management aims to appear unbiased and qualified in managing the process

\section{Inform the Minister} about the critical regional situation concerning the regional provision of vascular treatments Perform risk analysis for hospitals without vascular competence. Investigate the future need for vascular services

Reduce number of vascular centers and establish a strong regional vascular center in Oslo

Revoke centralizing
Consequences

The old regional organizational models need to be modified

Merger and decommissioning processes initiated by "modernizers"

The process is opened up (politicized), stirs up the local and "traditionalist" stakeholders Some stakeholders still consider management to be biased and disqualified plans, require future resource and quality measures for vascular services
These changes indicate that the management had prepared poorly for the process and put the "modernizers" on the defensive side The power configuration is altered in favor of the

"traditionalists"

The decision-making process is extended

The board needs to review situation and power configuration between "traditionalists" and "modernizers" The board concludes the decision-making process

\section{Decision- making in vascular surgery}

Table 2.

Timeline - main events in the decision-making process regarding the organization of vascular treatments at the South Eastern Norway Regional Health Authority 


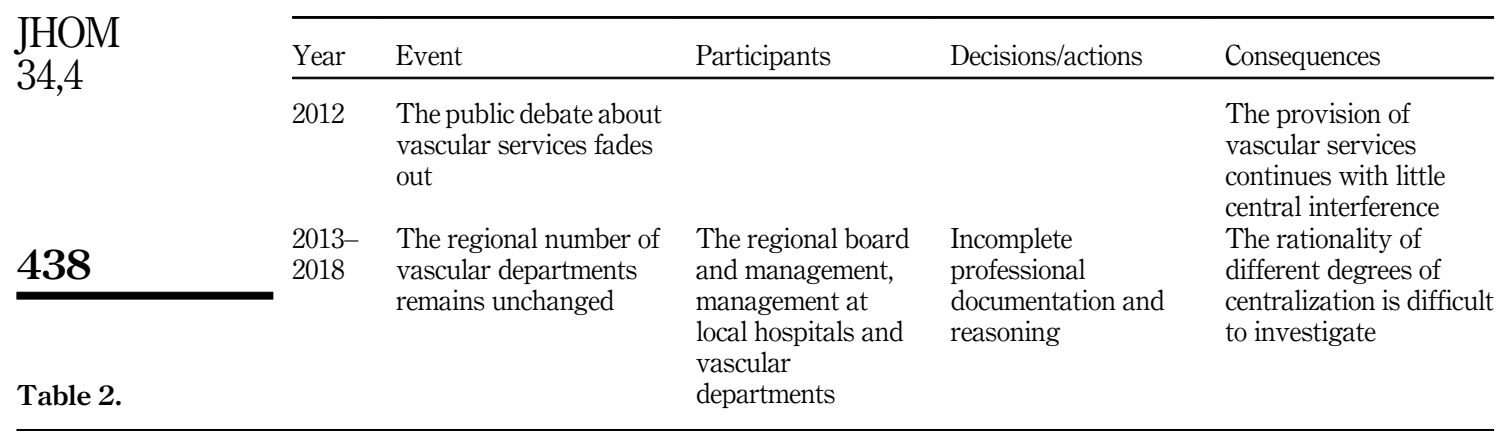

hospital purposes only. The plan to close down and sell the hospital was overturned. The board and the municipality of Oslo then resumed a long-lasting and still ongoing process of redefining the use of Aker Hospital (Hungnes and Hvidsten, 2018). These events also affected the vascular services at this location and made it even more difficult to agree on the location of the various vascular services. This shows how a particular decision-making process can be related to, and affected by, other processes. This is a well-known strategy for politicians who want to derail a particular process.

The hospital had large budget overruns and in April 2011, the hospital board and the CEOimposed major budget reductions on all the divisions (Oslo universitetssykehus, 2011a). They stopped the expansion of the Intervention Centre and the planned transfer of vascular surgical treatments to this site. The CEO resigned in June 2011 following disagreements with the board's long-term economic plans and the further development of the merged hospital. The board appointed a temporary CEO, only to replace him in December 2011. (Thorstein, 2011; Oslo universitetssykehus, 2011b)

Some of the informants commented on the messy Oslo situation. Informant 2, a "centralizer," said: "The P5 concluded that vascular surgery at Aker Hospital was to move almost immediately to Rikshospitalet. Nevertheless, the project was "parked." Oslo University Hospital got a new CEO (2011) and then the hospital lacked NOK 17 billion (for future investments - authors' comment). No decisions were made the next 2 years."

Informant 4, who initially had agreed to the conclusions from previous reports and committees, had spent a lot of time and effort on planning organizational change at his/her treatment site. He/she now only felt frustrated and disillusioned: "We were told that vascular surgery from Aker Hospital was going to move to Rikshospitalet but nothing happened. There were rumors about downsizing, but we did not know who would be affected. It was the absence of decisions that was troublesome."

Despite budget constraints, several committees and projects continued to work with the relocation of vascular treatments. The Department of Cardiothoracic surgery, traditionally representing a very influential professional field, also got involved. Informant 7 , who had indepth knowledge of this field said: "The Department of Cardiothoracic surgery did not agree to the initial plans of transferring all vascular surgery to Rikshospitalet. The hospital has neither the capacity to treat nor nurse all these patients." The thoracic environment had their own challenges concerning the organization of their heart and lung surgery, which was situated at both Rikshospitalet and Ullevål Hospital. In the so-called $\mathrm{O}+$ project, their main proposal was to transfer emergency treatments and critical heart surgery to Rikshospitalet and planned heart, lung and vascular surgery to Ullevål Hospital. In contrast, the management at the Department of Vascular Diseases, in a report called Kar+, recommended transferring all vascular treatments to Rikshospitalet. The various parties were constantly looking for ways 
of linking and relinking, defining and redefining locational issues and changing the decisionmaking "landscape." Thus, «modernizers» were dragged into the difficult - mostly traditional - art of maneuvering in a process that became increasingly diffuse and many-faceted ones.

To avoid costly anesthesiological preparedness at Aker Hospital for treatment of approximately 30 area and local patients with ruptured aortic aneurysms yearly, the hospital management decided to transfer these patients to Rikshospitalet in October 2011. Initially, the vascular surgical environment perceived this as a first step toward colocating vascular treatments at Rikshospitalet. Instead, they soon discovered that the vascular surgeons at Aker Hospital were obliged to work at a third treatment site. Thus, pragmatically based "small" decisions may disturb the larger decision-making landscape.

In April 2012, the management at Oslo University Hospital presented a summary of the propositions from $\mathrm{O}+$ and $\mathrm{Kar}+$, but emphasized that outpatient vascular services, day surgery and the circulation physiology laboratory had to remain at Aker Hospital. Despite the recommendation in the Kar+ report, one of the vascular surgeons at Rikshospitalet now suggested transferring hospitalized vascular surgical patients from Aker to Rikshospitalet and local vascular patients and day surgery to Ullevål hospital.

To avoid escalating the conflict, the CEO affirmed the decision to transfer hospitalized vascular surgical patients to Rikshospitalet and demanded a new relocation plan in May 2012. The CEO unsuccessfully tried to show authority. The situation at Rikshospitalet soon became even more complicated.

Instead of completing the expansion of the Intervention Centre, other remodeling and construction projects were initiated at Rikshospitalet to handle the transfer of vascular patients. This included upgrading two rooms at one of the three surgical units at the hospital and converting a washing unit for beds to a postoperative unit. Other departments than the vascular took these areas into possession because they urgently needed additional space. As a substitute, an operating room at another surgical unit was made available for future vascular surgery. However, no transfer of vascular patients took place and the decisionmaking process about vascular treatments seemingly faded out.

Informant 5 who had participated in the reorganization of vascular treatments at Oslo University Hospital from the start, said: "We have a lot of problems at this hospital: old buildings and the disputes between the different professional fields about location. Very little is actually about the vascular surgical field but this field has ended up in the midst of everything and is dragged in all directions." Multiple actors took uncoordinated initiatives at different times, creating outcomes that could not be traced back to anyone.

After the sudden stop in the expansion of the Intervention Centre caused by budget overruns at the hospital, the centre started its own fundraising. Through an extensive collaboration with internal and external actors, it received approximately NOK 35 million from the Research Council of Norway in 2016. When Siemens entered the stage with a substantial cut in MRI pricing, the hospital was pushed to finalize the long awaited expansion with NOK 100 million. The expansion, which was completed in October 2018, enabled the centre to offer advanced imaging and surgery in five suites. Several departments and professionals at Rikshospitalet, including the vascular surgeons employed at the Department of Cardiothoracic Surgery, began to use its expertise and the new hybrid rooms.

The management of Oslo University Hospital organized new meetings to find a solution for the Department of Vascular Diseases and its patients. During the Summer of 2019, the localand area-level patients with ruptured aortic aneurysms were transferred from Rikshospitalet to Ullevål hospital. In 2020, the plans are to transfer the hospitalized vascular surgical patients from Aker to Ullevål hospital. Day surgery, outpatient consultations and the national circulation physiology laboratory for research and patient examinations are to remain at Aker hospital and the responsibility for national and regional level patients at Rikshospitalet.
Decisionmaking in vascular surgery 
JHOM 34,4
Summing up, Oslo University Hospital has not colocated vascular surgical treatments to one treatment site despite several attempts over many years (Table 3).

\section{Discussion}

We have tried to describe, characterize and unravel the logics underlying one regional and one local decision-making process about vascular services in Norway: should these services, as a response to the development of knowledge and technology, become more centralized, or should they remain decentralized? In our first case, vascular services were to be moved from some local hospitals to larger regional hospitals. In the second case, they were to move from one, and partly two, hospitals to a third. We will now apply our theoretical framework on these two processes.

\subsection{Application of the framework on the two processes}

Today most researchers agree that actors are boundedly rational. They lack the cognitive capacities and problem-solving abilities to have clear goals, to conduct extensive information search and to prioritize between alternatives. They satisfice rather than optimize (Simon, 1947). Organizations therefore need clear goals and strategies and a clear division and coordination of labor across units. Occasionally decision-makers make rational choices, in other cases they do not (Eisenhardt and Zbaracki, 1992). This is illustrated in the two processes described in this paper. The decision-makers goals were unclear, their preferences unstable and affected by arguments, and they did not choose the optimal actions.

The two processes evolved in complex settings, with multiple actors with partly conflicting goals and interests. This resonates with the political perspective on organizational decision-making (Pfeffer, 1981; Lindblom, 1959). The top decision-making boards and managers initially listened to the modernizing professionals who recommended more centralization, in reality a decommissioning and merging (Pinheiro et al., 2017) of vascular services. But after the hospital reform in 2002, the "traditionalists" had become more active, strategic and vocal. Even restricted issues, like the organization of vascular surgery became parts of extensive processes concerning "decommissioning and mergers" in society in general (Torjesen et al., 2017).

The "modernizers" failed in both cases, because they had neither prepared well for selling their "plans" (Williams et al., 2017) to the "local" professionals, politicians and community activists, nor managed to mobilize key professionals as spokespersons. The decision-making processes turned into strategic games with many participants. Hence, the decision-making processes related to the location of vascular surgery became entangled with other processes.

Fleeting power configurations characterized both processes. The senior managers did not always know where they had their superiors and their tenure was often short. To some extent, the managers were more concerned about "surviving" than of being bold, strategic leaders.

Regionally, the centralizers tried to act responsibly and professionally by aiming to prevent a politicization of the issue. The role of numerical democracy and corporate pluralism had to be curtailed and "provincial" politicians, local interest groups and "self-serving" professionals held at bay. Nevertheless, through these closely connected channels and to some extent through the mass media, "disturbing" premises managed to influence the decision-making in both processes. Resonating Werntoft and Edberg (2015) as well as Williams et al. (2017), the "traditionalists" allied with the media and put the politicians including the Minister under pressure. The regional centralizers were curtailed by pressure from above. Hence, the regional provision of vascular services remained almost unchanged.

The process at Oslo University Hospital was more "internal'. What made this process stall was initially the popular mobilization of resistance against closing down Aker Hospital. 


\begin{tabular}{|c|c|c|c|}
\hline Year & Event & Participants & Decisions/actions \\
\hline \multirow[t]{2}{*}{2009} & $\begin{array}{l}\text { The merger of } \\
\text { Rikshospitalet, Ullevål } \\
\text { and Aker Hospitals } \\
\text { into Oslo University } \\
\text { Hospital }\end{array}$ & $\begin{array}{l}\text { The new hospital } \\
\text { board, the temporary } \\
\text { CEO }\end{array}$ & $\begin{array}{l}\text { Coordinate the } \\
\text { activity of the merged } \\
\text { entity }\end{array}$ \\
\hline & $\begin{array}{l}\text { The first attempts to } \\
\text { colocate the vascular } \\
\text { treatments at Oslo } \\
\text { University Hospital }\end{array}$ & $\begin{array}{l}\text { Participants in the } \\
\text { "P-5"-project }\end{array}$ & $\begin{array}{l}\text { Transfer hospitalized } \\
\text { vascular patients from } \\
\text { Aker hospital to } \\
\text { Rikshospitalet and } \\
\text { perform the surgical } \\
\text { procedures at its } \\
\text { Intervention Centre }\end{array}$ \\
\hline 2010 & $\begin{array}{l}\text { Possible new facilities } \\
\text { for Oslo University } \\
\text { Hospital are } \\
\text { investigated }\end{array}$ & $\begin{array}{l}\text { The board at Oslo } \\
\text { University Hospital }\end{array}$ & $\begin{array}{l}\text { Close down Aker } \\
\text { Hospital and use } \\
\text { money from sale to } \\
\text { build new facilities }\end{array}$ \\
\hline
\end{tabular}

2011 Large budget overruns at Oslo University Hospital

The board and CEO disagree about economic plans Long-term plans from important stakeholders in the vascular surgical decision-making process completed $(\mathrm{O}+, \operatorname{Kar}+)$

\section{Emergency} preparedness for vascular services at Aker Hospital is economically challenging for the Division of Emergency and Critical Care

2012 Summary about relocation plans concerning vascular services is presented. Vascular community is divided

The CEO, the board and managers at Oslo University Hospital

Impose major budget reductions on all the

divisions; stop expansion of the Intervention Centre

The hospital board, the CEO

CEO resigns

The Department of Cardiothoracic surgery, The Department of Vascular Diseases

The plans display deviating views on how to organize the services

The hospital board,

The Division of

Emergency and

Critical Care, The

Department of

Vascular Diseases

Transfer patients with ruptured abdominal aortic aneurysms from Aker Hospital to Rikshospitalet

The hospital CEO

Transfer vascular surgical patients according to previous plans, make new relocation plan
Consequences

Initiates restructuring processes

Decisionmaking in vascular surgery

Initiates numerous meetings concerning locations for vascular patients and expansion of the Intervention Centre

Local resistance manages to reverse decision to close Aker hospital. Situation affects and derails vascular surgical decision-making process provision of vascular
The reorganization of vascular services becomes part of internal political issues at Oslo University Hospital The board assigns temporary and later permanent CEO Decision-making process becomes more and more diffuse and many-faceted. Makes it difficult for hospital management to pursue a centralizing policy

Decision disturbs the larger decisionmaking landscape. The vascular surgeons from Aker Hospital are obliged to work at a third treatment site

Decision-making process is prolonged and becomes even more complicated

(continued)
Table 3.

Timeline-main events in the decision-making process regarding the organization of vascular treatments at Oslo University Hospital from 2009-2019 
JHOM 34,4

\begin{tabular}{lllll}
\hline Year & Event & Participants & Decisions/actions & Consequences \\
\hline 2013 & $\begin{array}{l}\text { New remodeling/ } \\
\text { construction projects } \\
\text { initiated to coordinate } \\
\text { reception/treatment of }\end{array}$ & Several surgical units & $\begin{array}{l}\text { Other departments } \\
\text { than the vascular } \\
\text { achieve additional } \\
\text { space }\end{array}$ & $\begin{array}{l}\text { No transfer of } \\
\text { vascular patients is } \\
\text { initiated }\end{array}$ \\
\end{tabular}

vascular surgical

patients at

Rikshospitalet

2014- Decision-making

2015 process fades

2016 The Intervention

Centre receives

external funding and

price reduction on MRI

The Research Council of Norway, Siemens,

The Intervention

Centre

2018 The Intervention

Centre is finally expanded with a new

MR, CT and two

advanced surgical

suites

The decision-making process concerning the organizing of vascular services resumes

2019 Area/local patients with ruptured abdominal aortic aneurysm are transferred from Rikshospitalet to Ullevål hospital
Oslo University Hospital, The Research Council, The Intervention Centre, Siemens

The management at Oslo University

Hospital

The management at Oslo University Hospital
The Intervention Centre displays ambitions beyond restructuring vascular care

Several different departments and professionals use the expertise and the new hybrid rooms at this location

Assign steering group, project group and working group

Transfer hospitalized vascular surgical patients from Aker to Ullevål hospital in 2020. Day surgery and outpatients remain at Aker and national/ regional patients at Rikshospitalet

Table 3.

Besides, the vascular community was divided and the initial pressure to establish a strong, regional vascular centre in Oslo became weaker because no regional centralization of vascular treatments was completed. The relocation plans concerning vascular treatments ended up resembling an "escalating process of indecisiveness" (Denis et al., 2011).

The nondecision-making processes became more important than the explicit decisionmaking processes. Some coalitions took advantage of this situation. Other departments than the vascular achieved additional space because their managers were able to define more urgent needs. The Intervention Centre managed to expand its facilities despite not receiving any vascular patients from Aker Hospital. Its ambitions went far beyond restructuring vascular care; it wanted to become an even more important regional and national provider of cutting-edge, technology-based R\&D.

Inaction becomes a function not only of "traditionalists" thwarting the centralizing "modernizers" but also of "modernizers" stuck in a tug-of-war among each other. The fight of the Aker interests against the coalitions of the merged hospital exemplifies the former, while the struggle over space and other resources between some of the professional specialties exemplifies the latter. In this struggle, not only vascular surgeons especially but also 
radiologists are up against other, more prestigious, specialists. In such struggles, the "modernizers" become just as "parochial" as the "traditionalists".

The most dynamic factor in the development of health care is R\&D, which constantly provides new insights and technology. It thereby exerts a strong pressure on the sector and its organization. However, the existing organization always reflects a particular power configuration. Power wielders try to adopt new technology in ways that preserve their positions (Lindberg et al., 2017; Zetka, 2001), and professionals continuously work to defend established jurisdictions (Abbott, 1988; Freidson, 1986).

The processes we have studied "should" have been professional processes of plan-based decision-making followed up by obedient implementation. Instead, they developed into interest-laden "muddling through" processes (Lindblom, 1959). The "traditionalists" captured the regional process through raising it to the local and national political level. They captured the local process because they managed to bring it onto the ordinary political agenda and to politicize it at the hospital level.

The key professionals "should" have represented the regional and local enterprises and the requirements posed by the new technology and knowledge. In both cases, they were influenced by other concerns. The central decision-makers tried to appear responsible. The "traditionalists" had not the same obligations. Regionally, they mobilized various stakeholders and brought the "modernizers" on the defensive. Locally, the professional elites were divided and were part of strategic games.

The processes that we have studied took place in an institutional environment, and we observe how established norms, largely reflecting "the logic of appropriateness" (Byrkjeflot and Neby, 2008; March and Olsen, 1989) became important. When the "traditionalists" allied with media and gained public attention, multiple external actors questioned the organizational issues. The decision-makers had to pay attention to these actors to maintain legitimacy Indecision was better than making controversial decisions.

\subsection{Strengths and limitations}

Medicine and its accompanying technology have developed fast since the Second World War, and they have become the major source of change in the organization of health care. In the first generation after the war, organizational change was gradual. Since the 1990s, the supply side innovations, and the growing concerns about costs while keeping access thresholds low, makes more radical change necessary. Our study illustrates how difficult it is to change a publicly and not very competitively exposed health care system. Christensen et al. (2008) and Porter and Lee (2013) show that this tension between "traditionalists" and "modernizers" plays a great role also in the US system. Both point to more competition as necessary to challenge the traditional structures.

Our findings are presented in a relatively anonymized way due to regulations and ethical considerations. If we had identified persons and the interpersonal dramas in our stories, we could have expanded our explanations. However, our closeness to the processes would have made it difficult to keep a sufficient analytic distance. If resource use and quality performance data were available, we could have examined the rationality of different degrees of centralization more profoundly. Similar studies should be conducted in other areas, also in a cross-country comparative way.

\subsection{Conclusion}

This paper contributes with a theoretical framework that explains how decision-making processes about organization of health care might concurrently be characterized by bounded rationality, interest politics and logic of appropriateness. In addition, we pay specific attention to how nondecisions and "escalating indecisiveness" (Denis et al., 2011) matters.
Decisionmaking in vascular surgery 
JHOM 34,4
In our cases, the managers and their professional advisers failed to convince their critics that scale reforms were the right solution. Despite accepting the new technology, the "traditionalists" insisted that its introduction demanded scant organizational adjustments. Nevertheless, medical changes on both the supply and the demand side have implications for the structuring of the provision of vascular services. As medicine develops, it is important constantly to consider the organization of its practice. Christensen et al. (2008) argue that intuitive conditions should be taken care of in so-called "solution shops", probabilistic conditions in shielded, chain-like organizations and precisely understood conditions in either chain or network organizations or even by patients and their relatives at home. Many of the vascular diseases belong to all domains. Once precisely diagnosed, they can be treated in a chain-like organization. However, the treatment is rarely conclusive. For many (older) patients the conditions are chronic and requires long-term follow-up. The "total" cycle of care thus becomes extensive, and it involves both professional and lay participants, and patient behavior adaptation, preventively and therapeutically. Thus, vascular service cuts across institutional boundaries. Something like Integrated Practice Units (Porter and Lee, 2013) may be called for. In our cases, the participants in the decision-making processes did not consider this aspect of vascular care. The "modernizers" were too hospital-oriented and too myopic regarding the full needs of their patients.

In many ways, the processes we have studied stalled. The central decision-makers at both levels found themselves at a loss how to take the next steps. To look at the development of the supply and need/demand and ask what it implies for the organization of care, could be a way to "open" the process again. Both "modernizers" and "traditionalists" should participate in that process.

\section{References}

Abbott, A. (1988), The System of Professions: An Essay on the Division of Expert Labor, University of Chicago Press, Chicago.

Bacharach, S.B. and Lawler, E.J. (1980), Power and Politics in Organizations, Jossey-Bass, San Francisco, California.

Byrkjeflot, H. and Neby, S. (2008), "The end of the decentralised model of healthcare governance? Comparing developments in the Scandinavian hospital sectors", Journal of health Organization and Management, Vol. 22, pp. 331-349.

Choi, S., Holmberg, I., Löwstedt, J. and Brommels, M. (2011), "Executive management in radical change - the case of the Karolinska University Hospital merger", Scandinavian Journal of Management, Vol. 27, pp. 11-23.

Christensen, C., Grossman, J. and Hwang, J. (2008), The Innovator's Prescription: A Disruptive Solution for Health Care, McGraw-Hill, New York.

Cohen, M.D., March, J.G. and Olsen, J.P. (1972), “A garbage can model of organizational choice”, Administrative Science Quarterly, pp. 1-25.

Cyert, R.M. and March, J.G. (1963), A Behavioral Theory of the Firm, Englewood Cliffs, NJ, Vol. 2, pp. 169-187.

Dahrendorf, R. (1964), Homo Sociologicus, Springer, Wiesbaden.

Denis, J.L., Dompierre, G., Langley, A. and Rouleau, L. (2011), "Escalating indecision: between reification and strategic ambiguity", Organization Science, Vol. 22, pp. 225-244.

Eisenhardt, K.M. and Zbaracki, M.J. (1992), "Strategic decision making", Strategic Management Journal, Vol. 13, pp. 17-37.

Fredriksson, M. and Moberg, L. (2018), "Costs will rather increase: actions and arguments against decommissioning in local health services in Sweden", Journal of health organization and management, Vol. 32, pp. 943-961. 
Freidson, E. (1986), Professional Powers, University of Chicago Press, Chicago.

Garpenby, P. and Bäckman, K. (2016), "Formal priority setting in health care: the Swedish experience", Journal of Health Organization and Management, Vol. 30, pp. 891-907.

Giddens, A. (1998), The Third Way: The Renewal of Social Democracy, Polity Press.

Goodney, P.P., Beck, A.W., Nagle, J., Welch, H.G. and Zwolak, R.M. (2009), "National trends in lower extremity bypass surgery, endovascular interventions, and major amputations", Journal of Vascular Surgery, Vol. 50, pp. 54-60.

Grønlie, T. (2006), "Norwegian general hospitals, 1970-2002: county ownership—an interlude between welfare localism and state direction", Medical History, Vol. 50, pp. 189-208.

Hatlen, S. (2010), Styresak 9/2010 - Suksess gjennom samhandling - utvikling av lokalsykehusfunksjonen $i$ Oslo universitetssykehus.

Helse Sør-Øst (2008), Sak Nr 108-2008 Omstillingsprogrammet - Innsatsområde 1 - Hovedstadsprosessen.

Helse Sør-Øst (2010), Sak Nr 084-10 - Funksjonsfordeling av karkirurgi i Helse Sør-Øst.

Helse Sør-Øst (2011), Sak Nr 060-2011 - Funksjonsfordeling av karkirurgi i Helse Sør-Øst.

Hsieh, H.F. and Shannon, S.E. (2005), "Three approaches to qualitative content analysis", Qualitative Health Research, Vol. 15, pp. 1277-1288.

Hungnes, T. and Hvidsten, A.H. (2018), "A controversy of interpretation: emergent agencies in repurposing Aker Local Hospital”, in Hoholm, T., La Rocca, A. and Aanestad, M. (Eds) Controversies in Healthcare Innovation, Palgrave Macmillan.

Kristoffersen, R. (2010a), "Reddet benet mitt”, Fredrikstad Blad, 1 December, p. 1.

Kristoffersen, R. (2010b), "SØ-ansatte skal møte Østfoldbenken”, Fredrikstad Blad, 8 December, p. 1.

Le Fanu, J. (1999), The Rise and Fall of Modern Medicine, Basic Books, New York.

Lincoln, Y.S. and Guba, E.G. (1986), "But is it rigorous? Trustworthiness and authenticity in naturalistic evaluation", New Directions for Program Evaluation, 1986, pp. 73-84.

Lindberg, K., Walter, L. and Raviola, E. (2017), "Performing boundary work: the emergence of a new practice in a hybrid operating room", Social Science and Medicine, Vol. 182, pp. 81-88.

Lindblom, C.E. (1959), “The science of 'muddling through", Public Administration Review, pp. 79-88.

Lægreid, P., Opedal, S. and Stigen, I.M. (2005), "The Norwegian hospital reform: balancing political control and enterprise autonomy", Journal of Health Politics, Policy and Law, Vol. 30, pp. 1027-1064.

Magnussen, J., Hagen, T.P. and Kaarboe, O.M. (2007), "Centralized or decentralized? A case study of Norwegian hospital reform”, Social Science and Medicine, Vol. 64, pp. 2129-2137.

March, J.G. and Olsen, J.P. (1989), Rediscovering Institutions: The Organizational Basis of Politics, The Free Press, New York.

March, J.G. and Simon, H.A. (1958), Organizations, Wiley, New York.

Myhre, H.O. (2012), "Vascular surgery", in Haffner, J., Gerner, T. and Jacobsen, A. (Eds), Surgery in Norway, Norwegian Surgical Society, Oslo, pp. 200-206.

Norkar (2016), Årsrapport, St. Olavs hospital.

Norsk Karkirurgisk Forening (2002), Struktur og organisering av Norsk karkirurgi i fremtiden, Den norske legeforening.

Oslo Universitetssykehus, H. (2011a), Sak 39/2011 - Beslutningssak - tiltak for A gjennomføre budsjett 2011.

Oslo Universitetssykehus, H. (2011b), Protokoll ekstraordinart telefonstyremøte 05.06.2011.

Pfeffer, J. (1981), Power in Organizations, Ballinger Publishing Company, Cambridge.

Pinheiro, R., Aarrevaara, T., Berg, L.N., Geschwind, L. and Torjesen, D.O. (2017), "Strategic mergers in the public sector: comparing universities and hospitals”, in Tarba, S.Y., Cooper, C.L., Sarala,
Decision-

making in

vascular

surgery

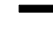


JHOM 34,4

R.M. and Ahammead, M.F. (Eds), Mergers and Acquisitions in Practice, Routledge, Oxon/ New York, pp. 44-68.

Porter, M.E. and Lee, T.H. (2013), "The strategy that will fix health care”, Harvard Business Review, Vol. 91, pp. 1-19.

Scott, J. (2000), "Rational choice theory", in Browning, G.H., Halcli, A. and Webster, F. (Eds), Understanding Contemporary Society: Theories of the Present, Sage Publications, London, pp. 126-138.

Sillesen, H. (2009), “Organisering av karkirurgi i Helse Sør-Øst”, Helse Sør-Øst RHF.

Simon, H.A. (1947), Administrative Behaviour, The free press, New York.

Sjølie, S.I. (2010), "Skriflig spørsmål fra Sonja Irene Sjølie (H) til helse- og omsorgsministeren", Dokument $n r, 15$, p. 435, (2010-2011), innlevert 2.12.2010, Stortinget.

Skiphamn, S.S. (2010), Mikkelsen må gå, Drammens Tidende, 3 December, p. 1.

Skjebstad, H.M. (2010), Selger Aker for å finansiere Ullevål, Groruddalen, 17 December, p. 1.

Sæther, O.D., Hatlinghus, S., Ellekjær, H., Aune, S., Jenssen, G., Aspevik, R. and Hasselgård, T. (2011), "Sluttrapport fra Sæther-utvalget, Faglige avhengigheter og risiko ved behandling av pasienter med karsykdom”, Helse Sør-Øst.

Thorstein, R. (2011), Siri Hatlen trekker seg, Dagens Medisin, 6 June, p. 1.

Torjesen, D.O., Foss Hansen, H., Pinheiro, R. and Vrangbæk, K. (2017), "The Scandinavian model in healthcare and higher education: recentralising, decentralising or both?", Scandinavian Journal of Public Management, Vol. 21 No. 1, pp. 103-122.

Werner-Erichsen, R. (2012), Ikke selg Aker tomta! Behold den til sykehusformål, Dagsavisen, 15 May, p. 1.

Werntoft, E. and Edberg, A.K. (2015), "Swedish politicians' view of obstacles when dealing with priority settings in health care", Journal of Health Organization and Management, Vol. 29, pp. 532-542.

Williams, I. (2015), "Receptive rationing: reflections and suggestions for priority setters in health care", Journal of Health Organization and Management, Vol. 29, pp. 701-710.

Williams, I., Harlock, J., Robert, G., Mannion, R., Brearley, S. and Hall, K. (2017), "Decommissioning health care: identifying best practice through primary and secondary research - a prospective mixed-methods study", Health Services and Delivery Research, Vol. 5 No. 22, pp. 1-226.

Yin, R.K. (2014), Case Study Research: Design and Methods, Sage Publications Inc., Thousand Oaks.

Zetka, J. (2001), "Occupational divisions of labor and their technology politics: the case of surgical scopes and gastrointestinal medicine", Social Forces, Vol. 79, pp. 1495-1520.

\section{About the authors}

Kjersti Wendt is Research Coordinator/PhD student at the Intervention Centre, Oslo University Hospital. She has a Master of Science in Values-Based Leadership, and she has a long and varied experience as nurse manager and nurse anesthetist. Her research is about trends in treatments in the area of vascular surgery, and she has published in European Journal of Vascular and Endovascular Surgery and in British Medical Journal Open. Kjersti Wendt is the corresponding author and can be contacted at: kwendt@ous-hf.no

Bjørn Erik Mørk is an Associate Professor of Innovation at BI Norwegian Business School. He is currently Research Center Leader for the Centre for Healthcare Management and Program Director for Healthcare Management at BI Norwegian Business School. In addition, he is an Honorary Associate Professor at IKON Research Centre, Warwick Business School (UK). He draws upon practice-based approaches in his research on innovation processes, the use of new technologies in organizations, boundary work, cross-disciplinary collaboration, power and learning. He has published in journals such as Academy of Management Annals, Human Relations, Social Science and Medicine and Management Learning. 
Ole Trond Berg is a Norwegian political scientist and Professor Emeritus of Health Administration at the University of Oslo. In his research, he is interested in topics such as the European health care systems, central health administration systems, organization and management in the clinic, the physician role in a historical and comparative perspective and physicians and management leadership. He managed the planning of, and was the first director of the Center for Health Administration at the University of Oslo, and he has continued to play an important role in their leadership development educational programs. He has published many articles and books.

Erik Fosse is a specialist in general and thoracic surgery and is a Professor of Medicine at the Faculty of medicine, University of Oslo. Since 1996, he has been the Head of Department of the Intervention Centre at Oslo University Hospital (www.ivs.no), a clinical research department for development and quality assurance of new treatment measures and technologies in Medicine. The research comprises clinical, patient experienced and economical outcomes, as well as organizational studies. Erik Fosse has authored or co-authored more than 240 peer-reviewed scientific publications and several books in medicine and social science.

For instructions on how to order reprints of this article, please visit our website: 